\title{
Motivasjon for beregningsorientert biologi og sammenhengen med matematikk R2 fra videregående opplæring
}

\author{
June Edvarda Eliassen, Maria Vetleseter Bøe, Lex Nederbragt, Marthe Mjøen Berg, \\ Tone Fredsvik Gregers, Universitetet i Oslo
}

\begin{abstract}
SAMMENDRAG: Programmering og modellering har i de senere år blitt innført i høyere utdanning og ble innfort i skolen med fagfornyelsen fra høsten 2020. Det har skapt behov for mer kunnskap om motivasjon og læring i emner som integrerer programmering som et nytt element i ellers veletablerte fagdisipliner. Denne studien undersøkte motivasjon for beregningsorientering (programmering og modellering) ved studieprogrammet biovitenskap ved Universitetet i Oslo. Spørreundersøkelser basert på Eccles' forventning-verdi-modell ble gjennomfort ved semesterstart og -slutt i to påfølgende år (2018 og 2019), før og etter innføring av krav om matematikk R2 (R2kravet). Motivasjonsvariabler ble validert ved faktoranalyse og undersøkelse av indre konsistens. Resultatene viste at studentene hadde noe lavere mestringsforventning og mye lavere interesse for et emne som integrerer programmering $i$ biologi enn for studieprogrammet generelt. Nytteverdien var den sterkeste motiverende faktoren for emnet. Studenter med matematikk $\mathbf{2} 2$ hadde litt storre mestringsforventning til emnet enn de som ikke hadde denne fordypningen. Studentene med R2 opplevde likevel bare litt mindre utfordring med matematikk i emnet, og ingen forskjell i utfordringer knyttet til programmering i emnet, sammenlignet med studenter uten R2. Samtidig opplevde studenter med $\mathrm{R} 2$ litt større utfordring med biologien i emnet, og det viste seg at studenter med full fordypning i $\mathrm{R} 2$ hadde mindre biologi fra videregående opplaring enn studenter uten R2. Resultatene droftes i lys av motivasjonsteori med tanke på implikasjoner for undervisning, inntakskrav og videre forskning.
\end{abstract}

\section{Introduksjon}

Det pågår nå en innføring av programmering og modellering i skolen, som følge av de nye læreplanene (LK20), og i høyere utdanning, blant annet for å møte kompetansebehov i fremtiden (21st Century Skills) (NOU 2014:7, 2014). Denne innføringen vil by på både muligheter og utfordringer. For eksempel åpner programmering for å behandle mer realistiske problemstillinger i utdanningen, og det vil gi studentene verdifull kompetanse som i større og større grad trengs i arbeidslivet. Samtidig vil det for mange studenter være utfordrende å møte programmering for første gang i høyere utdanning i årene før LK20 har rukket å gi alle erfaring med programmering fra skolen. Studentene lærer nå en helt ny ferdighet som en integrert del av studiene, uten å ha forkunnskaper om programmering å bygge på, slik de har i for eksempel lesing og regning.

Ved Universitetet i Oslo (UiO) jobber Center for Computing in Science Education (CCSE) med å gjøre programmering og realistiske problemstillinger til en integrert del av høyere utdanning og skolen (Universitetet i Oslo, 2016). Ved studieprogrammet biovitenskap ved Institutt for biovitenskap (IBV) ved UiO møter studentene programmering og modellering i biologi allerede fra første semester i emnet BIOS1100 - Innføring $i$ beregningsmodeller for biovitenskap. Pensum og oppgaver i BIOS1100 tar for seg biologiske problemstillinger som ligger nært opp mot pensum i andre emner som inngår i studieprogrammet (Universitetet i Oslo, 2020). Studier 
av motivasjon for beregningsorientert biologi blant studenter på dette studieprogrammet vil kunne gi implikasjoner for blant annet hvordan beregningsorientert undervisning bør tilrettelegges for biologistudenter.

Motivasjon er viktig både for læring og trivsel i studier (Ryan \& Deci, 2000). Tidligere forskning tyder på at ungdom ofte velger studieprogram i stor grad basert på hva de synes er interessant og meningsfylt (Schreiner et al., 2010). For studenter i biovitenskap antas det at interessen i starten av studiet er større for den biologifaglige delen av studiet enn for programmering, i og med at Berg (2019) fant at svært få av begynnerstudentene på biovitenskap i Oslo hadde noe særlig programmeringserfaring. Det er derfor nyttig å studere studenters motivasjon for programmering i studieprogrammer der studentenes primære motivasjon kommer fra deres interesse for faget og ikke programmeringen som de i liten grad kjenner til.

Slike studier er også viktig for å forstå frafall blant realfagstudenter, spesielt for dem som opplever studiet som annerledes enn de hadde sett for seg (Ulriksen et al., 2015). En tidligere studie har sett på hvordan og hvorfor interesse endret seg i løpet av semesteret i et emne i begynnerprogrammering. Opplevd mestring ga positiv interesseutvikling, mens en lærerstyrt ovenfra-og-ned-tilnærming til faget påvirket interesseutviklingen negativt (Scaico et al., 2017). Bergin og Reilly (2005) studerte effektene av indre og ytre motivasjon på studentprestasjoner ved et begynneremne i programmering. Resultatene viste at både indre motivasjon og mestringsforventning korrelerte sterkt med prestasjoner i programmering. Wiedenbeck et al. (2007) fant derimot at mestringsforventning ikke kunne predikere prestasjoner i programmering, mens interesse klart predikerte prestasjoner. Forskningen på feltet spriker altså til en viss grad, og det er få studier som spesifikt ser på programmering som del av studier i biovitenskap. Dette understreker behovet for forskning på området.

Programmeringserfaring har vist seg å være en fordel for motivasjon når studenter møter programmering i høyere utdanning (Ramalingam et al., 2004; Wiedenbeck et al., 2007). Ramalingam og kolleger (2004) fant at mestringsforventning påvirkes av tidligere programmeringserfaring. Studentene ved studieprogrammet biovitenskap har til nå hatt svært lite programmeringserfaring (Berg, 2019), og det er sannsynlig at innføring av programmering i skolen vil ha liten effekt $i$ høyere utdanning før studentene som har hatt programmering $i$ videregående opplæring som starter høsten 2023. Først da vil studieprogrammer kunne bygge på dette grunnlaget og legge opp undervisningen til et annet nivå og på en annen måte.

Kunnskaper fra matematikk kan hjelpe studenter med algoritmisk tenkning (Gomes et al., 2006; Pacheco et al., 2008) og slik gjøre det lettere å mestre emner som bruker programmering som verktøy (jf. BIOS1100), i tillegg til å bidra direkte i den matematiske delen av realfagsstudier. Høsten 2019 ble det innført et krav om full fordypning i realfaglig matematikk (R2-kravet) for studieprogrammet biovitenskap (Kunnskapsdepartementet, 2018). Innføringen har skapt debatt mellom ansatte og studenter ved universitetene, blant annet om i hvilken grad den ekstra matematikkompetansen er nødvendig og hvordan det påvirker rekrutteringen (Hellesund, 2019). Studieprogrammet biovitenskap ved UiO opplevde nesten en halvering i søkertall og oppmøte samme år som kravet ble innført, men høsten 2020 hadde biovitenskap-studiet ved UiO det høyeste søkertallet av alle biologiprogrammene i Norge (Valberg, 2020). Selv om søkertallet var høyt, var det likevel ikke flere studenter som møtte til undervisning høsten 2020 enn høsten 2019 (studieadministrasjonen, IBV).

Både full fordypning i biologi (Loehr et al., 2012) og matematikk (McMillan \& Edwards, 2019) har vist seg å være en fordel for prestasjoner i biologistudier. Ved at studentene har grunnleggende kunnskap om ulike fagområder innen biologi kan ny kunnskap settes i sammenheng med forkunnskaper for å skape en mer kompleks forståelse av biologi (Wadouh et al., 2014). Matematikk har på sin måte vist seg å fremme mestringsforventning til 
begynneremner i programmering (Wilson \& Shrock, 2001). Likevel kan kompetansenivå i matematikk være avgjørende for i hvilken grad studenter har fordel av matematikk i programmeringen (McMillan \& Edwards, 2019), og har vist seg å være en fordel i møte med programmering for første gang (Gomes et al., 2006; Gomes \& Mendes, 2008; Shute et al., 2017; Wilson \& Shrock, 2001). Siden tidligere studier har vist at både full fordypning i henholdsvis biologi og matematikk er en fordel for å studere biologi, er det viktig å finne ut av hvilke forkunnskaper som kan fremme motivasjon for beregningsorientering i BIOS1100 og studieprogrammet biovitenskap generelt.

I denne studien ser vi på studentenes motivasjon for beregningsorientert biologi generelt, og hvordan den henger sammen med det å ha tatt matematikk R2 i videregående opplæring spesielt. Vi har derfor sammenlignet motivasjonen i emnet BIOS1100 før og etter innføring av krav om full fordypning i realfaglig matematikk (R2-kravet) og for studenter med og uten R2 før kravet ble innført (Samordna opptak, 2019). Vi stilte følgende forskningsspørsmål:

1) Hvor stor interesseverdi, nytteverdi og mestringsforventning hadde studenter $\mathrm{i}$ biovitenskap til emnet BIOS1100 og til studieprogrammet biovitenskap?

2) På hvilken måte og i hvilken grad var motivasjonen ulik for studenter med og uten full fordypning i realfaglig matematikk før kravet ble innført?

3) Hvordan endret studentenes fagbakgrunn fra videregående opplæring seg da krav om full fordypning i matematikk ble innført?

\section{TEORETISKE PERSPEKTIVER}

Denne studien bruker motivasjonsteoretiske perspektiver, spesielt Eccles' og kollegers forventning-verdi-modell (Eccles et al., 1983; Eccles \& Wigfield, 2002). Modellen tar for seg hvordan mestringsforventning til en aktivitet, og den subjektive verdien aktiviteten har for studenten, motiverer studenten til deltakelse. Den subjektive verdien kan deles inn i fire: interesseverdi, nytteverdi, personlig identitetsverdi og relativ kostnad. Denne studien fokuserer på de to førstnevnte. Interesseverdi gir indre motivasjon (Ryan \& Deci, 2000) og handler om i hvilken grad studenten opplever aktiviteten i seg selv som interessant og har glede av den (Eccles \& Wigfield, 2002). For eksempel vil en student som synes en programmeringsoppgave i biologi er spennende knytte interesseverdi til oppgaven. Interessen kan være trigget av ulike deler av oppgaven, for eksempel at den handler om et område av biologien studenten er spesielt interessert $\mathrm{i}$ eller at den bruker verktøy $\mathrm{i}$ utforskingen som studenten synes det er spennende å jobbe med. Nytteverdi gir ytre motivasjon (Ryan \& Deci, 2000) og handler derimot om i hvilken grad studenten ser aktiviteten som et nyttig middel for å nå et annet mål (Eccles \& Wigfield, 2002). For eksempel kan studenter tenke at programmeringskunnskaper vil hjelpe dem i en framtidig jobb eller bidra til at de oppnår en mastergrad. Interesse kan endre seg over tid og $\mathrm{i}$ møte med ulike opplevelser. For å bedre forstå resultater knyttet til interesse, brukes Hidi og Renningers fire-fase-modell for interesseutvikling, som skiller mellom situasjonell og individuell interesse (Hidi \& Renninger, 2006). Situasjonell interesse er interesse som oppstår i en gitt situasjon og ofte forsvinner igjen når det som trigget interessen forsvinner. Individuell interesse er mer robust og langvarig, og driver studentene til å selv oppsøke aktiviteter som lar dem dyrke interessen. For å kunne forstå resultatene knyttet til mestringsforventning, brukes Banduras mestringsforventningsteori i tillegg til Eccles-modellen. Teorien forklarer hvordan mestringsforventning til en aktivitet er avgjørende for både prestasjoner, utførelse og resultater (Bandura, 1978). 


\section{METODE OG ANALYSE}

\subsection{Datamateriale}

Datamaterialet i denne studien består av besvarelser fra fire spørreundersøkelser som ble gjennomført i første og siste forelesning i emnet BIOS1100 høsten 2018 og 2019. Tabell 2 viser fordelingen av respondenter på spørreskjema 1 (SS1) og spørreskjema 2 (SS2) høsten 2018 og 2019.

Tabell 1: Deltagelse i sporreundersøkelsene. Forste sporreundersokelse (SS1) ble foretatt i forste forelesning som var obligatorisk både hosten 2018 (H18) og 2019 (H19). Andre sporreundersøkelse (SS2) ble foretatt i siste forelesning som ikke var obligatorisk.

\begin{tabular}{c|c|c|c|c|c|c|c|c} 
Semester & $\begin{array}{c}\text { Oppmeldt til } \\
\text { emnet BIOS1100 }\end{array}$ & \multicolumn{2}{|c|}{ Ordinær eksamen } & \multicolumn{4}{|c|}{ Respondenter } & \multicolumn{2}{c}{ Kjønn* } \\
& & Leverte & Besto & SS1 & SS2 & Besvarte SS1 og SS2 & Kvinner & Menn \\
\hline H18 & 182 & 157 & 117 & 158 & 103 & 93 & $84(81,6 \%)$ & $19(18,4 \%)$ \\
\hline H19 & 109 & 94 & 71 & 99 & 63 & 52 & $48(76,2 \%)$ & $15(23,8 \%)$
\end{tabular}

*Høsten 2018 ble det ikke spurt om kjønn i spørreskjema 1. Kjønnsfordelingen gjelder bare for spørreskjema 2.

Data er samlet inn med spørreskjemaer basert på Eccles'-modellen (Eccles et al., 1983; Eccles \& Wigfield, 2002) og Vilje-con-valg-undersøkelsen (Schreiner et al., 2010), og tilpasset populasjonen vi studerte. Siden spørreundersøkelsene ble foretatt ved semesterstart (SS1) og slutt (SS2), ble påstandene formulert forskjellig ut ifra ulike tidsperspektiv. Spørsmålene målte motivasjonsaspektene mestringsforventning, interesseverdi og nytteverdi for emnet BIOS1100 og for studieprogrammet biovitenskap ved UiO. Hoveddelen av spørreskjemaet besto av påstander med en 4-punkts likertskala, valgt for å unngå opphopning i midtkategori, der 1 var «ikke viktig/svært liten grad» og 4 var «veldig viktig/svært stor grad». Ti påstander målte motivasjonsaspektene interesseverdi (4), mestringsforventning (3) og nytteverdi (3) av programmering og modellering $i$ emnet BIOS1100. Tilsvarende målte sju påstander interesseverdi (4) og mestringsforventning (3) for studieprogrammet. Disse påstandene er presentert i henholdsvis tabell 3 og 4 (se Analyse). Siden spørsmålene som målte nytteverdien til emnet handlet om emnets nytte for studieprogrammet som helhet, kunne ikke et tilsvarende sett spørsmål lages for nytteverdien til studieprogrammet. Resten av spørreskjemaene målte andre aspekter som kunne henge sammen med motivasjonen. Disse aspektene var forkunnskaper innen biologi og matematikk fra videregående opplæring, utfordringer i emnet BIOS1100 og interesser for tema innen biologi.

\subsection{Analyse}

Eksistensen av de tre teoretisk funderte dimensjonene mestringsforventning, interesseverdi og nytteverdi ble validert ved hjelp av eksplorerende faktoranalyse i IBM SPSS Statistics (Field, 2018). En Kaiser-Meyer-Oklin-testverdi på 0,74 for emnet og 0,50 for studieprogrammet viste at utvalget var stort nok for korrelasjonsbasert faktoranalyse (Field, 2018). Bartletts test demonstrerte at korrelasjonene gjorde det mulig å trekke ut faktorer (Field, 2018). Direct oblimin-rotasjon ble brukt, siden det tillater at faktorene er korrelerte, som de teoretisk sett er forventet å være (Eccles \& Wigfield, 2002). Ved hjelp av Kaisers kriterium valgte vi å trekke 
ut tre faktorer (Field, 2018), og det viste seg at påstandene som ladet på de ulike faktorene samsvarte med det vi forventet teoretisk. For å validere at faktorene kunne giøres om til samlevariabler, ble indre konsistens (Cronbachs alpha) regnet ut og funnet tilstrekkelige for alle samlevariablene for emnet basert på kriteriet på >0,7 (Pallant, 2016).

Tabell 2: Faktoranalyse motivasjonskonstrukt emnet BIOS1100

\begin{tabular}{|c|c|c|c|c|c|}
\hline Påstander & $\begin{array}{l}\text { Ladning } \\
\text { faktor } 1\end{array}$ & $\begin{array}{l}\text { Ladning } \\
\text { faktor } 2\end{array}$ & $\begin{array}{l}\text { Ladning } \\
\text { faktor } 3\end{array}$ & Samlevariabel & $\begin{array}{l}\text { Cronbachs } \\
\text { alpha }\end{array}$ \\
\hline $\begin{array}{l}\text { Emnet kommer til å handle om noe jeg synes } \\
\text { er spennende }\end{array}$ & 0,772 & & & \multirow{4}{*}{$\begin{array}{l}\text { Interesseverdi } \\
\text { (emnet) }\end{array}$} & \multirow{4}{*}{0,82} \\
\hline Jeg er svært motivert for emnet & 0,686 & & & & \\
\hline Jeg kommer til å trives med emnet & 0,648 & 0,437 & & & \\
\hline $\begin{array}{l}\text { Emnet vil ta opp temaer jeg mener er } \\
\text { meningsfulle og viktige }\end{array}$ & 0,599 & $-0,350$ & 0,308 & & \\
\hline $\begin{array}{l}\text { Jeg kommer til å gjøre det bedre enn de fleste } \\
\text { av mine medstudenter }\end{array}$ & & 0,740 & & \multirow{3}{*}{$\begin{array}{c}\text { Mestrings- } \\
\text { forventning } \\
\text { (emnet) }\end{array}$} & \multirow{3}{*}{0,72} \\
\hline $\begin{array}{l}\text { Jeg er bekymret for at jeg ikke kommer til å } \\
\text { være flink nok i emnet (reversert skala) }\end{array}$ & & 0,713 & & & \\
\hline $\begin{array}{l}\text { Det kommer til å bli lett for meg å lære } \\
\text { fagstoffet i BIOS } 1100\end{array}$ & & 0,608 & & & \\
\hline $\begin{array}{l}\text { Emnet vil gi meg kunnskap og ferdigheter som } \\
\text { blir viktig videre i studiet }\end{array}$ & & & 0,894 & & \\
\hline $\begin{array}{l}\text { Jeg ser verdien av emnet for det jeg skal lære } \\
\text { videre i studiet }\end{array}$ & & & 0,778 & Nytteverdi & 0,78 \\
\hline Emnet vil gi meg kunnskap og ferdigheter som & & & 0,485 & (emnet) & \\
\hline
\end{tabular}
blir viktig i en fremtidig jobb

Samlevariabelen for mestringsforventning til studieprogrammet har en mer uklar faktorløsning enn den tilsvarende samlevariabelen for emnet, og Cronbachs alpha er lavere enn kriteriet (se Tabell 4) (Pallant, 2016), noe som må tas hensyn til i videre tolkning av denne. For å kunne sammenligne mestringsforventning for emnet og studieprogrammet ble det likevel laget samlevariabel for mestringsforventning for studieprogrammet, og ekstra forsiktighet er utvist $\mathrm{i}$ tolkning av resultatene.

Tabell 3: Faktoranalyse motivasjonskonstrukt studieprogrammet biovitenskap

\begin{tabular}{|c|c|c|c|c|}
\hline Påstander & $\begin{array}{l}\text { Ladning } \\
\text { faktor } 1\end{array}$ & $\begin{array}{l}\text { Ladning } \\
\text { faktor } 2\end{array}$ & Samlevariabel & $\begin{array}{l}\text { Cronbachs } \\
\text { alpha }\end{array}$ \\
\hline $\begin{array}{l}\text { Studieprogrammet kommer til å handle om noe jeg synes er } \\
\text { spennende }\end{array}$ & 0,834 & & \multirow{4}{*}{$\begin{array}{l}\text { Interesseverdi } \\
\quad \text { (studiet) }\end{array}$} & \multirow{4}{*}{0,81} \\
\hline Jeg er svært motivert for studieprogrammet & 0,822 & & & \\
\hline Jeg kommer til å trives på studieprogrammet & 0,755 & & & \\
\hline $\begin{array}{l}\text { Studieprogrammet vil ta opp temaer jeg mener er } \\
\text { meningsfulle og viktige }\end{array}$ & 0,567 & & & \\
\hline $\begin{array}{l}\text { Jeg kommer til å gjøre det bedre enn de fleste av mine } \\
\text { medstudenter }\end{array}$ & & 0,636 & \multirow{3}{*}{$\begin{array}{c}\text { Mestrings- } \\
\text { forventning } \\
\text { (studiet) }\end{array}$} & \multirow[b]{3}{*}{0,64} \\
\hline $\begin{array}{l}\text { Jeg er bekymret for at jeg ikke kommer til å være flink nok } \\
\text { på dette studieprogrammet (reversert skala) }\end{array}$ & 0,325 & 0,212 & & \\
\hline $\begin{array}{l}\text { Det kommer til å bli lett for meg å lære fagstoffet i } \\
\text { studieprogrammet }\end{array}$ & & 0,940 & & \\
\hline
\end{tabular}


Tre faktorer for emnet og to faktorer for studieprogrammet ble bekreftet. Cronbachs alpha for samlevariabelen mestringsforventning (studiet) er på bare 0,64 , og dermed noe under kriteriet på $>0,7$. Vi valgte likevel å bruke den med forsiktighet, for at den samlevariabelen best skulle korrespondere til mestringsforventning (emnet). Samlevariablene ble laget slik at respondentenes samlevariabelskår er lik det aritmetiske gjennomsnittet av skårene på påstandene i samlevariabelen.

\section{Forskjeller mellom ulike gruppers skår}

Effektstørrelser på forskjeller mellom ulike grupper eller samme gruppe ved ulike tidspunkt ble regnet ut ved hjelp av Cohens $d$ (Cohen, 1988). Det finnes ulike versjoner av Cohens d. Formelen som er brukt her tar hensyn til at gruppene som sammenlignes har ulike standardavvik (McGrath \& Meyer, 2007):

$$
d=\frac{\bar{X}_{1}-\bar{X}_{2}}{s_{p}}, \operatorname{der} s_{p}=\sqrt{\frac{\left(N_{1}-1\right) s_{1}^{2}+\left(N_{2}-1\right) s_{2}^{2}}{N_{1}+N_{2}}}
$$

Der $\bar{X}_{1}$ og $\bar{X}_{2}$ er gjennomsnittsverdiene, $N_{1}$ og $N_{2}$ er antall respondenter og $s_{1}$ og $s_{2}$ er standardavvikene til henholdsvis gruppe $1 \mathrm{og} 2$. Størrelsen på forskjellen kan være $d$-verdier mellom 0 og 2, der $d<0,2$ er definert som ingen forskjell, $0,2 \leq d<0,5$ er liten forskjell, $0,5 \leq$ $d<0,8$ er middels forskjell og $d \geq 0.8$ er stor forskjell (Cohen, 1988).

\section{RESULTATER}

Først presenteres generell motivasjon for emnet BIOS1100 og studieprogrammet biovitenskap blant alle studenter ved semesterstart høst 2018 (H18) og høst 2019 (H19), for å svare på det første forskningsspørsmålet med et overblikk over den generelle motivasjonen både før og etter R2-kravet ble innført. Det vil si at 2018-dataene i kap. 4.1 inneholder studenter med og uten matematikk R2. Deretter besvares det andre forskningsspørsmålet ved å sammenligne resultater for studenter med og uten matematikk R2, og da brukes dataene fra før R2-kravet ble innført (H18). Alle forskjeller oppgis som Cohens $d$. Små forskjeller omtales som «litt større/mindre», middels forskjell omtales som «noe større/mindre», og store forskjeller som «mye større/mindre». Til slutt svarer vi på det tredje forskningsspørsmålet ved å se spesielt på studentenes fagbakgrunn i biologi fra videregående opplæring.

\subsection{Motivasjon for emnet BIOS1100 og studieprogrammet biovitenskap}

Det var ingen substansiell forskjell i motivasjon for emnet H18 sammenlignet med H19 (Fig. 1). Det var derimot forskjell mellom motivasjon for emnet og for studieprogrammet i 2019, da dette var en del av undersøkelsen. Studentene rapporterte mye større interesseverdi $(d=1,21)$ og noe større mestringsforventning $(d=0,48)$ for studieprogrammet som helhet enn for emnet. Når det gjaldt emnet, var nytteverdien en mye sterkere motiverende faktor enn interesseverdien $(d=1,29)$. Alle Cohens $d$ i dette avsnittet gjelder for H19. Det ble ikke spurt om nytteverdi for emnet eller motivasjon til studieprogrammet ved studiestart H18. 


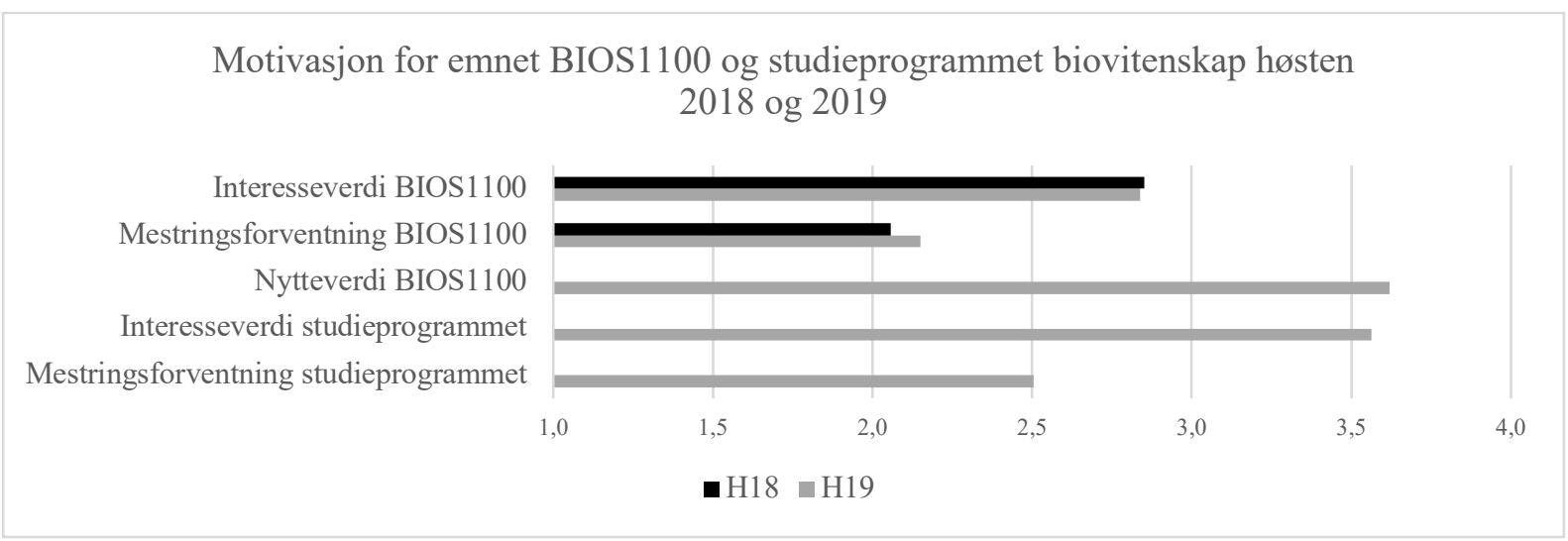

Fig. 1: Gjennomsnittsskår på motivasjonsvariabler H18 og H19 ved semesterstart (SS1). Påstander under overskriften «I hvilken grad er du enig i følgende påstander om deg og emnet BIOS1100/studieprogrammet» ble besvart på likert-skala (1-4), der 1 er «sveert liten grad» og 4 er «sveert stor grad». H18 N =149. H19 N =99.

Studentene forventet litt større utfordringer i matematikken i emnet før R2-kravet (H18) enn etter (H19) $(d=0,24)$ (Fig. 2). Sammenligning av utfordringer knyttet til ulike deler av emnet viser at de forventet langt mindre utfordringer knyttet til biologien enn til programmering $(d=$ $1,25)$ eller matematikk $(d=1,09)$ i emnet $(\mathrm{H} 19)$.

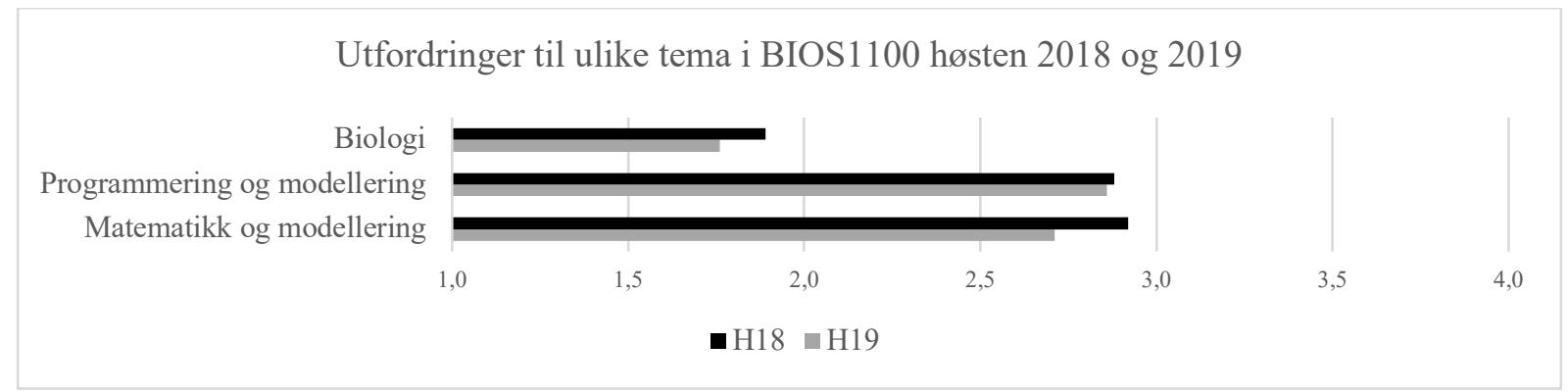

Fig. 2: Gjennomsnittskår på spørsmålet «I hvilken grad tror du følgende temaer blir en utfordring $i$ emnet BIOS1100?» på en skala fra «svcert liten grad» (1) til «svoert stor grad» (4). Alle respondenter ved semesterstart (SS1). H18 N=149. H19 N=99.

I et annet spørsmål kunne studentene krysse av for inntil tre områder innenfor biologi de var mest interessert i. Det var flere studenter som valgte tema innen genetikk, celle- og molekylærbiologi sammenliknet med tema innen økologi og evolusjon (Fig. 3). Samtidig krysset svært få studenter av for interesse for programmering og modellering i biologi.

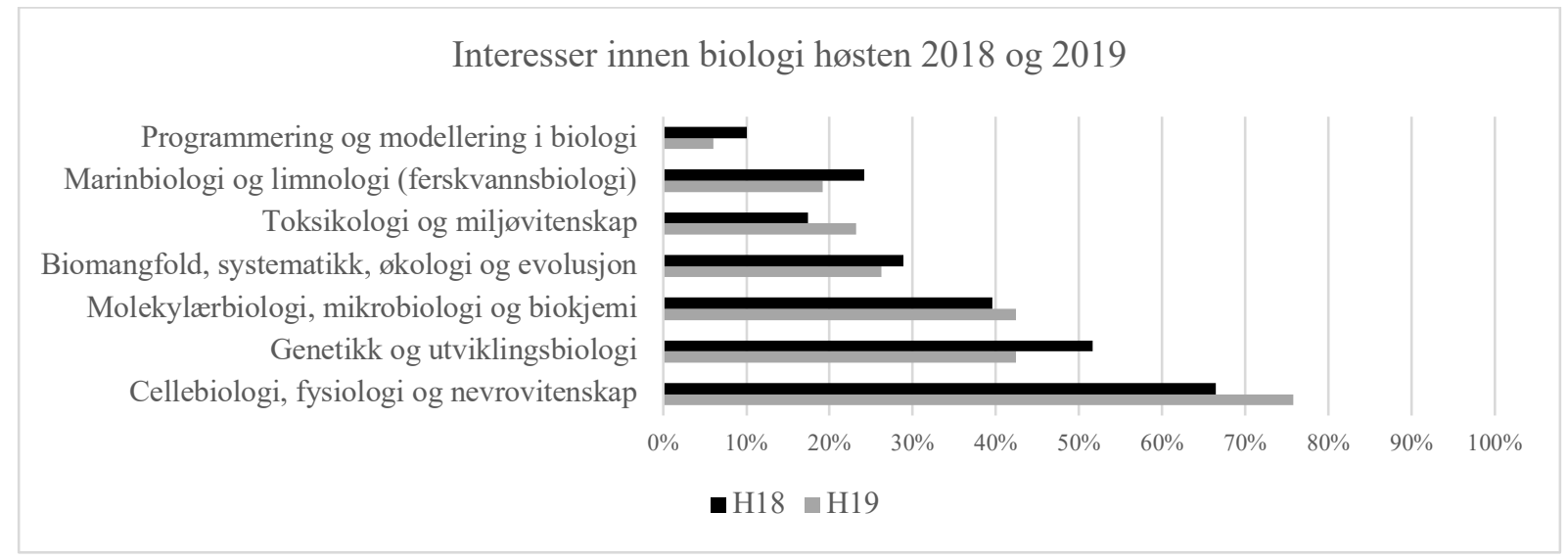

Fig. 3: Andel studenter som krysset av på spørsmålet «Hvilke tema er du mest interessert $i$ innen biologi?» på en skala fra «svoert liten grad» (1) til «svoert stor grad» (4). Alle respondenter ved semesterstart (SS1). H18 N=149 og H19 N=99. 


\subsection{Motivasjon for emnet BIOS1100 for studenter med og uten matematikk R2 høsten 2018}

Studentene med matematikk R2 uttrykte litt større mestringsforventning til emnet i slutten av semesteret enn studentene uten matematikk R2 høsten $2018(d=0,37)$ (Fig. 4). Interessen for emnet var lik for begge grupper både ved semesterstart (SS1) og-slutt (SS2).

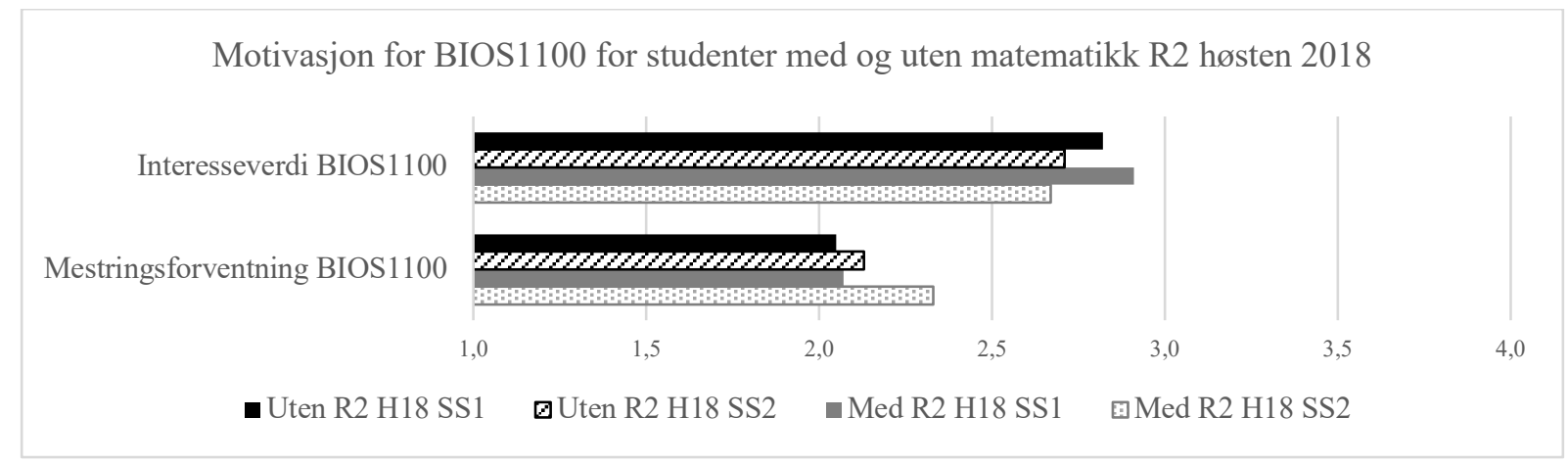

Fig. 4: Gjennomsnittsskår på motivasjonsvariabler for emnet BIOS1100 H18. Påstander under overskriften «I hvilken grad er du enig i følgende påstander om deg og emnet BIOS1100» ble besvart på likert-skala (1-4), der 1 er «Svcert liten grad» og 4 er «sveert stor grad». Uten $R 2 N=99$. Med $R 2 N=50$.

Studentene uten matematikk R2 så litt større utfordringer i matematikken i emnet $(d=0,45)$ enn studenter med R2 (Fig. 5). Samtidig så studentene med R2 litt større utfordringer knyttet til biologien i emnet $(d=0,36)$ enn studenter uten R2. Vi fant ingen forskjell mellom gruppene med tanke på utfordringer knyttet til programmeringen $i$ emnet.

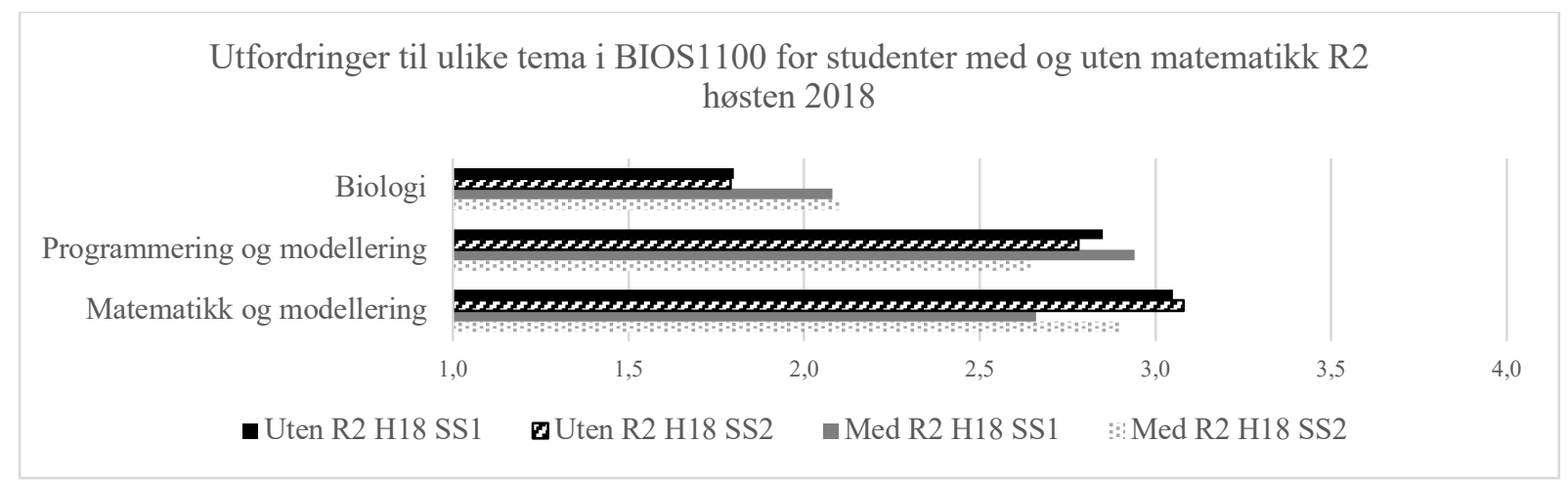

Fig. 5: Utfordringer til ulike tema i BIOS1100 H18. Gjennomsnittskår på spørsmålet «I hvilken grad tror du følgende temaer blir en utfordring i emnet BIOS1100?» på en skala fra «svcert liten grad» (1) til «svcert stor grad» (4) for studenter med og uten R2 H18. Uten R2 N=99. Med R2 N=50.

Interessene innen biologi var ganske like hos studentene med og uten R2, men det var noen forskjeller som er verdt å nevne (Fig. 6). En større andel (+ 13pp.) av studentene med R2 uttrykte interesse innen genetikk og utviklingsbiologi enn studentene uten R2. Samtidig uttrykte færre av studentene med R2 interesse innen marin- og ferskvannsbiologi (-18 pp.) sammenlignet med studentene uten R2. 
Interesser innen biologi hos studenter med og uten matematikk R2 høsten 2018

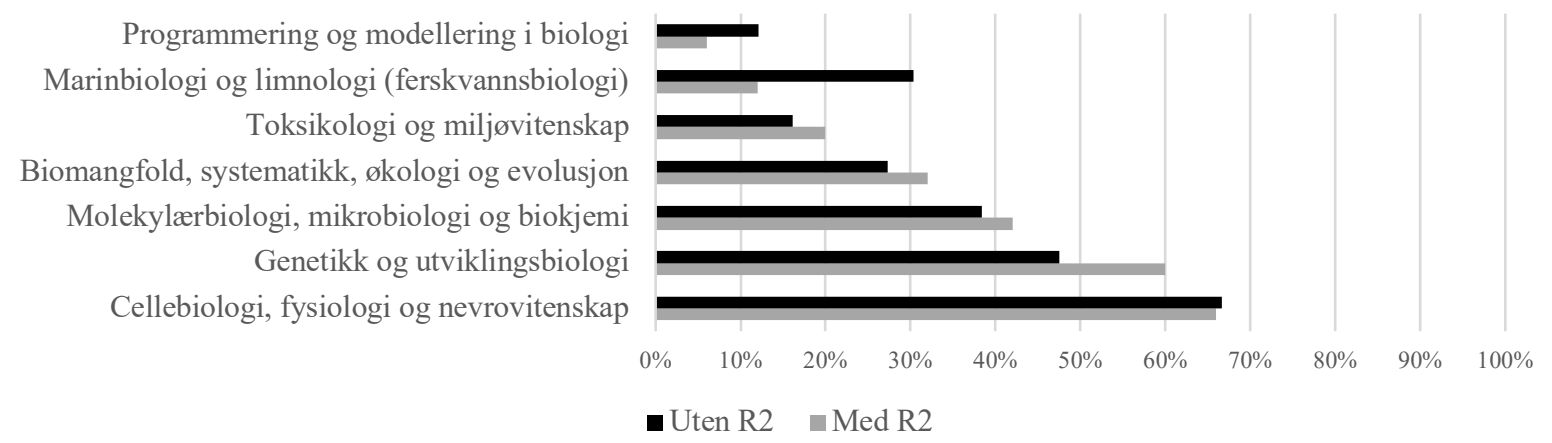

Fig. 6: Interesser innen biologi for studenter med og uten matematikk R2 H18. På spørsmålet «Hvilke tema er du mest interessert i innen biologi» kunne hver student krysse av for inntil 3 tema. Uten $R 2 N=99$. Med R2 $N=50$.

\subsection{Fagbakgrunn i biologi fra videregående opplæring}

Etter innføring av R2-kravet høsten 2019 hadde en mindre andel av deltakerne i vår studie full fordypning i biologi fra videregående opplæring enn året før kravet $(65,8 \%$ H18 og 59,6\% H19). Preliminære data fra høsten 2020 (H20) viser en ytterligere nedgang i antall studenter med full fordypning i biologi (Fig. 6). Data fra høsten 2018 viste at studenter uten R2 i langt større grad enn studenter med R2 hadde full fordypning i biologi, hhv. $78 \%$ og $48 \%$ (Fig. 6).

Fagbakgrunn i biologi fra videregående opplæring høsten 2018, 2019 og 2020

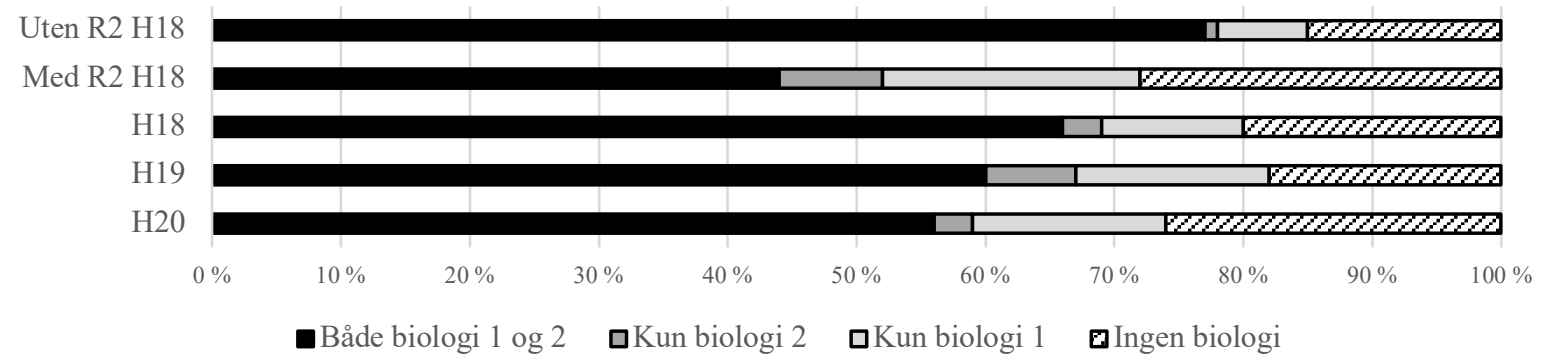

Fig. 7: Forkunnskaper i biologi fra videregående opplaering H18, H19 og H20 (Universitetet i Oslo, 2018).

\section{DISKUSJON OG IMPLIKASJONER}

\subsection{Motivasjon for beregningsorientert biologi generelt}

Studentene som deltok i denne studien uttrykte tydelig en annen motivasjon for programmering og modellering i biologi enn for studieprogrammet som helhet. Den sterkeste motivasjonsfaktoren for studieprogrammet var interesseverdi som gir indre motivasjon, mens motivasjonen for emnet BIOS1100 var dominert av nytteverdi, som gir ytre motivasjon. At studievalget ser ut til å ha vært interessebasert samsvarer med tidligere forskning både i Norge og internasjonalt (Schreiner et al., 2010; Ulriksen et al., 2015). Det kan være uheldig for studentenes trivsel og læring i programmeringsemnet at interesseverdien for emnet er såpass mye mindre enn for studieprogrammet. Interesse gir emosjonell og kognitiv belønning (Schunk et al., 2008), og styrker læring gjennom økt hukommelse, fokus og utholdenhet (Hidi \& Renninger, 2006). Nytteverdien studentene ser i emnet kan likevel ha gitt dem motivasjon som er hensiktsmessig for læring, hvis den er av en selvbestemt art der målet oppleves personlig verdifullt for studenten og ikke påtvunget (Ryan \& Deci, 2009). Spørsmålene som inngår i nytteverdivariabelen viser til nytten av emnet for det interessebaserte valget om å studere biovitenskap, og kan derfor ses på som personlig verdifullt og selvbestemt (Bøe, 2012; Deci \& 
Ryan, 2008; Eccles \& Wigfield, 2002; Ramberg, 2006). Samtidig tilsier resultatene at studentene i mindre grad vil oppleve glede ved læringsaktivitetene i seg selv i BIOS1100 enn i emner på studieprogrammet som de tematisk har større interesse for (Deci \& Ryan, 2008).

Studentene hadde også noe større mestringsforventning til studieprogrammet enn til emnet BIOS1100. Dette kan ses i sammenheng med at de så større utfordringer knyttet til programmering og matematikk enn til biologien i emnet, og at nettopp programmering og matematikk gjør at BIOS1100 skiller seg ut sammenlignet med andre emner studentene tok samme semester. Mestringsforventning er blant annet basert på i hvor stor grad studentene ser utfordringer knyttet til tema i emnet eller studieprogrammet, men også på hvilke ressurser studentene selv vurderer at de har i form av forkunnskaper (Bong \& Skaalvik, 2003; Skaalvik \& Skaalvik, 2015).

En måte å styrke studentenes motivasjon i BIOS1100 på er å videreutvikle nytteverdien de allerede ser i emnet. Helt konkret kan det handle om å framheve og vise hvordan programmering vil hjelpe dem i kommende emner og oppgaver, gjerne ved at studenter selv får være med og påvirke tema og problemstillinger. Det vil kunne bidra til opplevd relevans og selvbestemmelse, som er viktig for at ytre motivasjon skal fremme læring (Deci \& Ryan, 2008). En annen tilnærming vil være å prøve å øke interesseverdien, ved å vekke og utvikle studentenes interesse for programmering og modellering i biologi. Det kan for eksempel gjøres ved å hekte programmering konkret på noe de allerede er interessert $\mathrm{i}$ for å skape og videreutvikle situasjonell interesse (Hidi \& Renninger, 2006). Dette er til en viss grad allerede innbakt $\mathrm{i}$ emnet, siden det er et biologiemne som bruker programmering og modellering som verktøy. Effekten kan bli større av målrettet bruk av temaer studentene uttrykker stor interesse for, spesielt hvis disse kan knyttes til dagsaktuelle temaer. I skrivende stund våren 2021 vil det kunne være smitte, vaksiner, eller klimaendringer.

\subsection{Studenter med matematikk R2 opplevde storre mestring i BIOS1100}

I slutten av høstsemesteret 2018 hadde studenter med R2 noe større mestringsforventning til BIOS1100 enn studenter uten R2. Det tyder på at studentene med R2 hadde opplevd større mestring enn andre studenter underveis i semesteret. Antakelsen støttes av at studenter med R2 rapporterte at de hadde hatt mindre utfordringer med programmering i emnet enn de trodde de ville få ved semesterstart. Matematikk R2 inneholder komponenter som har vist seg å være en fordel når studenter møter programmering for første gang, for eksempel logisk og algoritmisk tenkning (Gomes et al., 2006; Gomes \& Mendes, 2008; Wilson \& Shrock, 2001). En masteroppgave gjennomført parallelt med vår studie fant at studentene i BIOS1100 benyttet seg av problemløsningsstrategier kjent fra matematikk og computational thinking når de løste oppgaver (Rudberg, 2020). Dette kan bety at ferdigheter fra matematikk R2 kan ha bidratt til at studentene med R2 i snitt opplevde større mestring enn studenter uten R2. Mestringsfølelse kan påvirke engasjement og utholdenhet og er viktig for prestasjoner og gjennomføring (Bandura, 1997; Bong \& Skaalvik, 2003; Schunk \& Mullen, 2012).

Det er likevel viktig å bemerke at mestringsforventningen til emnet er relativt lav sammenlignet med mestringsforventning til studieprogrammet, selv for studenter med R2. Det kan være flere årsaker til dette, men en av dem kan være at det er stor variasjon i kompetansenivået i R2gruppa. Når matematikk R2 blir et krav kan det øke sannsynligheten for at elever med lavere interesse og ferdighetsnivå velger faget for å tilfredsstille opptakskravet (Bøe, 2012) mer enn fordi de er interessert i det. Dette kan øke sannsynligheten for relativt dårlige resultater $\mathrm{i}$ matematikk R2. Preliminære data fra spørreundersøkelser høsten 2020 viser at studentene hadde 0,7 poeng lavere gjennomsnittskarakter $(3,6)$ enn landsgjennomsnittet $(4,3)$ i matematikk R2. Videre analyser av hvordan karakter i R2 henger sammen med både motivasjon og læring kan gi ytterligere kunnskap om hvordan matematikk R2 henger sammen med motivasjon i emnet. 


\subsection{Krav om matematikk R2 ser ut til å gå på bekostning av forkunnskaper i biologi}

Innføring av nye opptakskrav er gjort for å endre studentenes forkunnskaper slik at de er godt rustet til studiet de starter på. Økt mestring i et emne som BIOS1100 er sannsynligvis en ønsket effekt. Samtidig kan R2-kravet ha andre effekter som i mindre grad var ønsket. Våre resultater tyder på at kravet også har ført til svekkete forkunnskaper i biologi. En del studenter høsten 2019 så nemlig ut til å ha valgt full fordypning i matematikk på bekostning av biologi i videregående skole. Vi ser en klar forskjell i forkunnskaper i biologi mellom studenter med og uten R2, og vi ser at andelen studenter med full fordypning i biologi har gått ned etter at R2kravet ble innført. Studenter som har valgt bort full fordypning i biologi kan ha prioritert R2 fordi de konkret planla å søke opptak til studier i biovitenskap ved UiO, eller for å holde mulighetene åpne for å søke flere av de mange studieprogrammene med R2-krav (Bøe, 2012). Ved noen skoler kan det også være umulig å kombinere biologi 2 og R2 på grunn av kollisjon på timeplanen (Ramberg, 2006; Smyth \& Hannan, 2006). I alle tilfeller betyr resultatet at begynnerstudenter i biovitenskap er dårligere rustet for biologien i studieprogrammet etter at R2-kravet ble innført. Denne tolkningen styrkes av at disse studentene også opplevde betydelig større utfordringer knyttet til biologien i BIOS1 100 enn studenter med full fordypning i biologi. Sånn sett kan vi si at den økte matematikkompetansen til studentene har gått på bekostning av kompetanse i biologi. Videre forskning må til for å se om dette er en vedvarende trend $\mathrm{i}$ årene som kommer, og hvilke konsekvenser det kan få for studenters læring og motivasjon i biovitenskap. Tidligere forskning tilsier at både fordypning i biologi (Loehr et al., 2012) og i matematikk (McMillan \& Edwards, 2019) er et fortrinn for å lykkes med høyere utdanning i biovitenskap. Da er det er et tankekors om et godt grunnlag i matematikk svekker studentenes forkunnskaper i biologi.

I videre vurdering av R2-kravet bør ønskede effekter av kravet diskuteres opp mot hvilke effekter det ser ut til å ha og kunne få. For biovitenskap handler det blant annet om å veie ønsket om bedre mestring av matematikk og programmering på studiet opp mot viktigheten av solide forkunnskaper i biologi.

\subsection{Videre undersøkelser knyttet til motivasjon for beregningsorientert biologi}

Det er få studier på motivasjon for beregningsorientert biologi som er gjort i Norge. Det ville derfor være interessant å få en dypere forståelse for hva som kan hjelpe studenter når de møter en ny aktivitet som programmering. I tråd med at fagfornyelsen antageligvis kommer til å skape endringer i forkunnskaper om programmering og modellering hos studenter $\mathrm{i}$ årene fremover, er det nyttig om det samles inn data videre for å kunne si noe om effekten av dette. Flere andre faktorer kan også undersøkes knyttet opp mot funnene i denne artikkelen, for eksempel sammenhengen mellom motivasjon og karakterer fra videregående opplæring, og om høyere karakter i matematikk R2 gjenspeiler prestasjoner i BIOS1 100 målt i eksamenskarakterer.

\section{KONKLUSJON}

Denne artikkelen har presentert forskning på motivasjon for beregningsorientert biovitenskap blant studenter i første studieår på Universitetet i Oslo. Resultatene viste at studentene hadde litt lavere mestringsforventning og mye lavere interesse for et emne som integrerer programmering i biologi enn for studieprogrammet generelt. Dette gjør studentene sårbare i møte med motgang i emnet, siden de da har mindre interesse og mestring som kan drive dem. Den sterkeste motiverende faktoren for emnet var imidlertid nytteverdien. Vi argumenterer for at videreutvikling av nytteverdien og fokus på stimulering av interesse kan støtte studentenes motivasjon for emnet. Videre viste resultatene at studenter med matematikk R2 hadde litt større mestringsforventning til emnet enn de som ikke hadde denne fordypningen, og opplevde litt mindre utfordring med matematikk og ingen forskjell i utfordringer knyttet til programmering i emnet. Samtidig opplevde disse studentene større utfordring med biologien i emnet, og det 
viste seg at studenter med full fordypning i matematikk R2 i mindre grad enn studenter uten R2 hadde full fordypning i biologi fra videregående opplæring. På den måten viser resultatene en mulig «trade off» mellom styrkede forkunnskaper i matematikk og bedret mestring basert på det, og forkunnskaper og mestring i biologi, og det drøftes derfor om innføringen av R2-krav har gitt ønsket effekt.

\section{REFERANSER}

Bandura, A. (1978). Self-efficacy: Toward a unifying theory of behavioral change. Advances in Behaviour Research and Therapy, 1(4), 139-161. doi:https://doi.org/10.1016/0146-6402(78)90002-4

Bandura, A. (1997). Self-efficacy: The exercise of control. New York, NY, US: W H Freeman/Times Books/ Henry Holt \& Co.

Berg, M. M. (2019). Studentar si interesse og mestringsforventning for programmering og modellering i biologi. Retrieved from https://www.duo.uio.no/bitstream/handle/10852/70498/Masteroppg-ve_MartheMjenBerg.pdf? sequence $=11$ \&isAllowed $=\mathrm{y}$

Bong, M., \& Skaalvik, E. (2003). Academic Self-Concept and Self-Efficacy: How Different Are They Really? Educational Psychology Review, 15, 1-40. doi:10.1023/A:1021302408382

Bøe, M. (2012). Science choices in Norwegian upper secondary school: What matters? Science Education, 96, 120. doi:10.1002/sce.20461

Cohen, J. (1988). Statistical power analysis for the behavioral sciences. Hillsdale, N.J.: L. Erlbaum Associates.

Deci, E. L., \& Ryan, R. M. (2008). Self-determination theory: A macrotheory of human motivation, development, and health. Canadian Psychology/Psychologie canadienne, 49(3), 182-185. doi:10.1037/a0012801

Eccles, J., Adler, T., Futterman, R., Goff, S., Kaczala, C., Meece, J., \& Midgley, C. (1983). Expectations, values, and academic behaviors. In (pp. 75-146).

Eccles, J., \& Wigfield, A. (2002). Motivational Beliefs, Values and Goals. Annual Review of Psychology, 53, 109132. doi:10.1146/annurev.psych.53.100901.135153

Field, A. P. (2018). Discovering statistics using IBM SPSS statistics.

Gomes, A., Bigotte, E., Carmo, L., \& Mendes, A. (2006). Mathematics and programming problem solving.

Gomes, A., \& Mendes, A. (2008). A study on student's characteristics and programming learning.

Hidi, S., \& Renninger, K. A. (2006). The Four-Phase Model of Interest Development. Educational Psychologist, 41(2), 111-127. doi:10.1207/s15326985ep4102_4

Loehr, J. F., Almarode, J. T., Tai, R. H., \& Sadler, P. M. (2012). High school and college biology: a multi-level model of the effects of high school courses on introductory course performance. Journal of Biological Education, 46(3), 165-172. doi:10.1080/00219266.2011.617767

McGrath, R., \& Meyer, G. (2007). When effect sizes disagree: The case of $\mathrm{r}$ and d. Psychological methods, 11, 386-401. doi:10.1037/1082-989X.11.4.386

McMillan, J., \& Edwards, D. (2019). Performance in first year mathematics and science subjects in Australian universities: Does senior secondary mathematics background matter? Retrieved from Camberwell: https://research.acer.edu.au/higher_education/62/

NOU 2014:7. (2014). Elevenes laering $i$ fremtidens skole - Et kunnskapsgrunnlag. Kunnskapsdepartementet Retrieved from https://www.regjeringen.no/no/dokumenter/NOU-20147/id766593/?q=century\&ch=9\#KAP8

Pacheco, A., Gomes, A., Henriques, J., \& De Almeida, A. (2008). Mathematics and programming: some studies. 77. doi: $10.1145 / 1500879.1500963$

Pallant, J. F. (2016). SPSS survival manual : a step by step guide to data analysis using IBM SPSS / Julie Pallant. Sydney: Allen \& Unwin.

Ramalingam, V., LaBelle, D., \& Wiedenbeck, S. (2004). Self-efficacy and mental models in learning to program. Paper presented at the Proceedings of the 9th annual SIGCSE conference on Innovation and technology in computer science education, Leeds, United Kingdom. https://doi.org/10.1145/1007996.1008042

Ramberg, I. (2006). Realfag eller ikke? Elevers motivasjon for valg og bortvalg av realfag i videregånde opplæring. NIFU STEP. Retrieved from http://hdl.handle.net/11250/2357331

Rudberg, S. (2020). Relevansen av kompetansen fra matematikk R2 i beregningsorientert biologi. Retrieved from https://www.duo.uio.no/bitstream/handle/10852/79793/Relevansen-av-kompetansen-fra-matematikkR2.pdf?sequence $=1$ \&isAllowed $=\mathrm{y}$

Ryan, R., \& Deci, E. (2000). Intrinsic and Extrinsic Motivations: Classic Definition and New Directions. Contemporary Educational Psychology, 25, 54-67. doi:10.1006/ceps.1999.1020

Ryan, R., \& Deci, E. (2009). Promoting self-determined school engagement: Motivation, learning, and well-being. Samordna opptak. (2019). Endringer i regelverk. Retrieved from https://www.samordnaopptak.no/info/om/loverog-regler/endringer/ 
Scaico, P. D., Queiroz, R. J. G. B. d., \& Dias, J. J. L. (2017). Analyzing How Interest in Learning Programming Changes During a CSO Course: A Qualitative Study with Brazilian Undergraduates. Paper presented at the Proceedings of the 2017 ACM Conference on Innovation and Technology in Computer Science Education, Bologna, Italy. https://doi.org/10.1145/3059009.3059015

Schreiner, C., Henriksen, E. K., Sjaastad, J., Jensen, F., \& Løken, M. (2010). Vilje-con-valg:Valg og bortvalg av realfag i høyere utdanning. Naturfagssenteret(2/2010), 1-12. Retrieved from https://www.naturfagsenteret.no/c1515378/binfil/download2.php?tid=1509698

Schunk, D., \& Mullen, C. (2012). Self-Efficacy as an Engaged Learner. In (pp. 219-235).

Schunk, D. H., Pintrich, P. R., \& Meece, J. L. (2008). Motivation in Education: Theory, Research and Applications: Pearson College Division.

Shute, V., Sun, C., \& Asbell-Clarke, J. (2017). Demystifying computational thinking. Educational Research Review, 22. doi:10.1016/j.edurev.2017.09.003

Skaalvik, E., \& Skaalvik, S. (2015). Motivasjon for loering. Oslo: Universitetsforlaget.

Smyth, E., \& Hannan, C. (2006). School effects and subject choice: The uptake of scientific subjects in Ireland. School Effectiveness and School Improvement - SCH EFFECTIVENESS SCH IMPROV, 17, 303-327. doi:10.1080/09243450600616168

Ulriksen, L., Madsen, L., \& Holmegaard, H. (2015). The First-Year Experience: Students' Encounter with Science and Engineering Programmes. In (pp. 241-257).

Universitetet i Oslo. (2016). The centre's aims and vision. Retrieved from https://www.mn.uio.no/ccse/english/about/aims-and-vision.html

Universitetet i Oslo. (2018). Hvem er våre studenter? Retrieved from https://www.google.com/url?sa=t\&rct=j\&q=\&esrc=s\&source=web\&cd=\&ved=2ahUKEwidy9eonN_u AhWCxosKHQ-

XDbcQFjAEegQIARAC\&url=https\%3A\%2F\%2Fwww.mn.uio.no\%2Fom $\% 2$ Forganisasjon $\% 2 F u t v a l g$ \%2Fstudieutvalg\%2F2019\%2Fsakspapir\%2F190522-stut-hvem-er-varestudenter.docx\&usg=AOvVaw1TSlr2h-1NmkCmnxj_cISv

Universitetet i Oslo. (2020). BIOS1100 - innføring i beregningsmodeller for biovitenskap. Retrieved from https://www.uio.no/studier/emner/matnat/ibv/BIOS1100/

Valberg, A. (2020). Mattekrav stopper ikke søkerne. Retrieved from https://www.mn.uio.no/om/aktuelt/aktuellesaker/2020/sokertall-2020.html

Wadouh, J., Liu, N., Sandmann, A., \& Neuhaus, B. (2014). The effect of knowledge linking levels in biology lessons upon students' knowledge structure. International Journal of Science and Mathematics Education, 12. doi:10.1007/s10763-012-9390-8

Wiedenbeck, S., Sun, X., \& Chintakovid, T. (2007). Antecedents to End Users' Success in Learning to Program in an Introductory Programming Course.

Wilson, B., \& Shrock, S. (2001). Contributing to success in an introductory computer science course: A study of twelve factors (Vol. 33). 